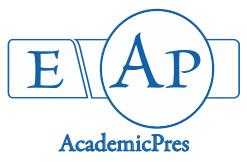

Dar AA and Jamal K (2021)

Notulae Scientia Biologicae

Volume 13, Issue 2, Article number 10906

DOI: $10.15835 / \mathrm{nsb} 13210906$

Research Article

\title{
Moth (Insecta: Lepidoptera) fauna of Sariska Tiger Reserve, Rajasthan, India
}

\author{
Afaq A. DAR*, Khowaja JAMAL \\ Aligarh Muslim University, Department of Zoology, 202002,Uttar Pradesh, India, afaqamuzoo@gmail.com \\ (*corresponding author);drkhowajajamal@gmail.com
}

\begin{abstract}
Survey to assess moth diversity was carried out in Sariska Tiger Reserve of Rajasthan in 2019 from June to November. Total 16 species were recorded under 15 genera, belonging to 5 families for the first time from Sariska Tiger Reserve. Of these, 12 species viz. Eudocima materna Linnaeus, 1767; Eudocima phalonia Linnaeus, 1763; Dysgonia stuposa (Fabricius, 1794); Euproctis divisia Walker, 1855; Achaea janata Linnaeus, 1758; Acherontia styx Westwood, 1847; Daphnis nerii Linnaeus, 1758; Hippotion rosetta (Swinhoe, 1892); Agrius convolvuli Linnaeus, 1758; Nephele hespera Fabricius, 1775; Theretra oldenlandiae (Fabricius, 1775); Caligula lindia Moore, 1865 were first time reports from the state. Moth species were collected with the help of a light sheet system operated every night from 9:00 pm to 2:00 am. Ethyl acetate fumes were used to kill collected speciemens and processed as per standard strategies in Lepidopterology. The identification of moths was carried out with the help of identification keys, standard reference keys. Family Erebidae and Sphingidae are represented by six species each, followed by Saturniidae represented by two species, Noctuidae and Crambidae represented by one species each. This study will improve our understanding of Sariska's biodiversity and be used to develop strategies for the conservation of moth diversity.
\end{abstract}

Keywords: India; moth; new records; Sariska Tiger Reserve

\section{Introduction}

The order Lepidoptera comprises of skippers, butterflies and moths. According to the recent study, 1, 65,000 species of moths have been reported globally (Khan and Perveen, 2015), among which 12,000 species of moths have been reported from India (Chandra and Nema, 2007). Moths play an important role in natural ecosystem, such as agricultural pests (Sharma and Bisen, 2013), food for various organisms such birds, bats and insects' species, night pollinators (Macgregor et al., 2015). Moths are widely accepted as the most sensitive indicators determining the quality of environment and changes occurring in it (Thomas, 2005). They also serve as research models for studying biodiversity conservation, evolution, genetics, ethology and genetics because of taxonomically well-known and quick identification nature (Samways, 2007). The dramatic decrease of moths is believed to have drastic effects on birds, bats and plants due to key stone role of moths in an ecosystem (Wickramasinghe et al., 2004; Jonasan et al., 2013).

In Indian sub-continent lepidopteran fauna were started by Linnaeus (1758); Cramer (1775); Fabricius (1775); Kollar (1884); Butler (1886); Devonian (1880). Later on, catalogues and lists were published by

Received: 16 Feb 2021. Received in revised form: 18 Mar 2021. Accepted: 07 May 2021. Published online: 19 May 2021.

From Volume 13, Issue 1, 2021, Notulae Scientia Biologicae journal uses article numbers in place of the traditional method of continuous pagination through the volume. The journal will continue to appear quarterly, as before, with four annual numbers. 
Walker (1854); Moore (1888); Kirby (1892); Cotes and Swinhoe (1886). Fauna of British India (Vol. I-IV) by Hampson (1892-1896) was one of the finest works on Indian and exotic moths, which was succeeded by Vol V. on Sphingidae by Bell and Scott (1937). Snellen and Elwes (1890) published a catalogue on Pyralidae of Sikkim, collected by Elwes \& Moller. Later on, Hampson $(1903,1918,1919)$ published supplementary paper on new moths collected by Mons. Sevastopulo (1965) reported moth fauna of Kolkata. Barlow (1982) studied and reported moth fauna of South East Asia. Gupta et al. (1984) published detailed description on Lymantridae of India. Mandal and Ghosh (1997); Mandal and Maulik (1997); Ghosh and Choudhury (1997), and Bhattacharya (1997) studied Heteroceran fauna of West Bengal. Arora (1983) reported moth fauna of Andaman \& Nicobar Island. Mandal and Ghosh (1991) described some moth species from Tripura.

Kirti and Sodhi, (2001) reported 113 species of Pyralidae moths from North-East part of India. Ghosh, (2003) reported 525 species of moths from Sikkim. Chandra (2007) reported 142 species of moths from Madhya Pradesh and Chhattisgarh belonging to 11 families. Gurule et al. $(2010 ; 2011 ; 2013 \mathrm{a})$ reported moth fauna from North Maharshtra. In further studies Gurule (2013b) reported 405 species from North Maharashtra. Chandra and Sambath (2013) reported 102 species of moths from Tawang district of Arunachal Pradesh. Gogoi et al. (2014) reported 104 species of moths from Arunachal Pradesh. Uniyal et al. (2016) reported 169 species of Geometrid moths from different protected areas of Uttarakhand. Sondhi and Sondhi (2016) reported 248 species of moths from Dehradun and Mussoorie and Devalsari in Tehri Garhwal District in Uttarakhand. Most recently, Chandra et al. (2019) reported 1274 species of moths belonging to 704 genera under 25 families from various regions of Indian Himalayan Region. Of them, 88 species of moths were novel to the Indian fauna.

India exhibits high diversity of moth fauna. Several studies have been carried out to explore moth fauna of Rajasthan. However, large area of Rajasthan is yet to be unexplored. To date, no comparable studies on moth diversity have been conducted in Rajasthan, India. In this study, we investigated the moth diversity in the tiger reserve of Rajasthan. Due to our study, a preliminary checklist of moth species was generated, which will probably serve as baseline for other researchers.

\section{Materials and Methods}

\section{Studyarea}

The study was conducted during 2019 from March to November in Sariska Tiger Reserve of Alwar District, Rajasthan. Sariska Tiger Reserve is located at $27^{\circ} 23^{\prime} 30^{\prime \prime} \mathrm{N}, 76^{\circ} 22^{\prime} 32^{\prime \prime} \mathrm{E}$, having total area of $881 \mathrm{~km}^{2}$. It forms a part of the Alwar district of Rajasthan and is nestled amidst the picturesque Aravalli Hill Range of Rajasthan. The Reserve is immensely rich in flora and fauna, and is famous for Royal Bengal Tiger. Sariska was declared wildlife sanctuary in year 1955 and became the Tiger reserve later in the year 1978, making it a part of India's Project Tiger. According to Champioan and Seth (1968) forest type reserve is tropical dry deciduous with dominant plant species Anogeissus pendula. Rajasthan is globally known for diverse flora and fauna (Shahabuddin and Kumar, 2006; Dashahre et al., 2014). Three sites were chosen for sampling viz. Kalighati, Karnakabas and Slopka inside the reserve based on different habitats and GPS coordinates of each site were noted (Figures 1 and 2). 


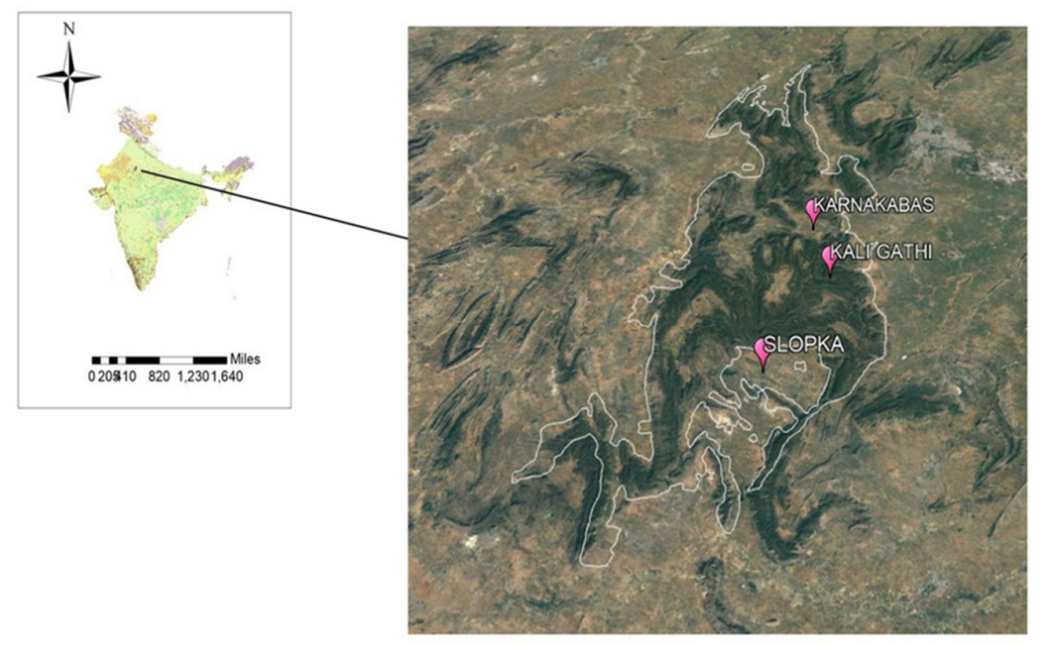

Figure 1. Map of sampling stations inside survey area

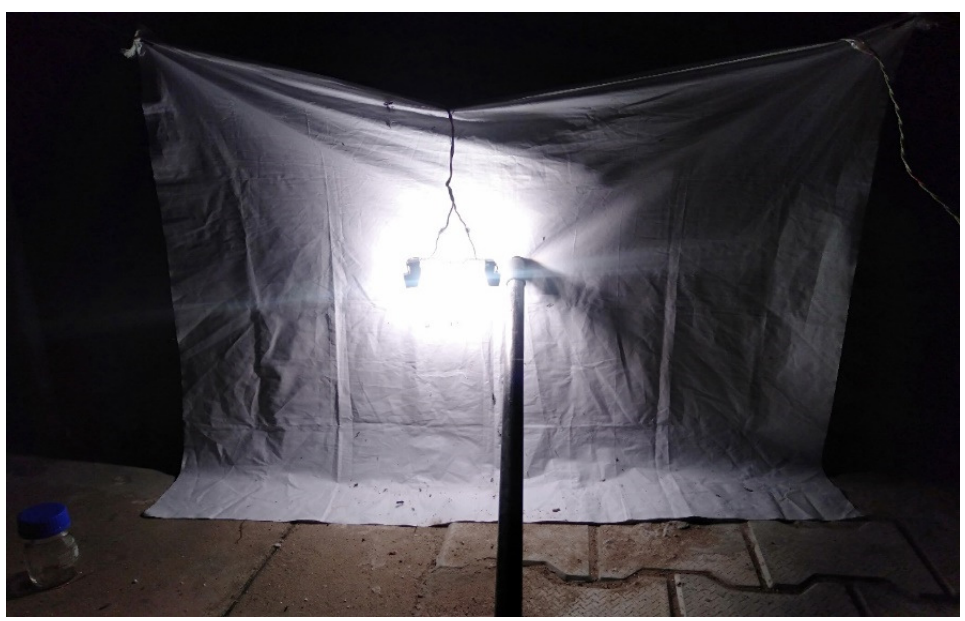

Figure 2. Light sheet used for collection of moths

Table 1. Overview of selected survey sites

\begin{tabular}{|c|c|c|}
\hline Survey sites & Forest type & GPS coordinates \\
\hline Kalighati & Mixed riparian forest & $27^{\circ} 21^{\prime} 29.95^{\prime \prime} \mathrm{N}, 76^{\circ} 29^{\prime} 29.34^{\prime \prime} \mathrm{E}$ \\
\hline Karnakabas & Slope forest & $27^{\circ} 25^{\prime} 23.17^{\prime \prime} \mathrm{N}, 76^{\circ} 28^{\prime} 28.87^{\prime \prime} \mathrm{E}$ \\
\hline Slopka & Scrub forest & $27^{\circ} 14^{\prime} 40.28^{\prime \prime} \mathrm{N}, 76^{\circ} 25^{\prime} 30.29^{\prime \prime} \mathrm{E}$ \\
\hline
\end{tabular}

\section{Collection and preservation of moths}

Legal permits required were obtained from Rajasthan Forest Department. The selected sites inside the reserve were surveyed with light sheet to assess moth species. A white cloth sheet $(4 \times 3 \mathrm{~m})$ was illuminated using Mercury Vapour lamp (250 watt) used as light sheet. Light sheet was operated each night from 9:00 pm to 2:00 am. The collected specimen was killed by ethyl acetate fumes and brought to laboratory for further processing. The killed specimens were pinned and spread using spreading board and preserved dry. Dry preservation was done in fumigated entomological boxes and stored in the insect boxes at Zoology Department of Aligarh Muslim University. 


\section{Identification}

The identification of moths was carried out with the help of identification keys, standard reference keys, available literature viz. Hampson (1892-1896); Bell and Scott (1937); Holloway (1987, 1999, 2005) and Kirti and Singh (2015). The classification system adapted as per van Nieukerken et al. (2011). In addition, a number of web resources including were used including www.jpmoths.org; Moths of India (http://mothsofindia.org/; Sondhi et al., 2020), http://www.flicker.com/groups/mothsof india/and iNaturalist (https://inaturalist.org) were used for identification.

\section{Results}

During the study 104 specimens of moths pertaining to 05 families were collected from the study area. From collected specimens total 16 species were identified viz. Eudocima materna Linnaeus, 1767; Eudocima phalonia Linnaeus, 1763; Dysgonia stuposa Fabricius, 1794; Achaea janata Linnaeus, 1758; Euproctis divisia Walker, 1855; Creatonotos interrupta (Linnaeus, 1767); Archerontia styx Westwood, 1847; Agrius convolvuli Linnaeus, 1758; Nephele hespera Fabricius, 1775; Hippotion rosetta Swinhoe, 1892; Daphnis nerii Linnaeus, 1758; Theretra oldenlandiae (Fabricius, 1775); Caligula lindia Moore, 1865; Actias selene Hubner, 1807; Spodoptera litura Walker, 1857 and Diaphania indica Saunders, 1851.

Family Erebidae and Sphingidae dominate the fauna ( 6 species each), followed by Saturniidae ( 2 species) and Family Noctuidae and Crambidae with single species each. The present study is very first record of moth fauna from Sariska Tiger Reserve of Rajasthan.

Taxonomic illustrations

1. Eudocima materna (Linnaeus, 1767)

Material Examined: Rajasthan: Alwar, Sariska Tiger Reserve (Kalighati), 2721'29.95”N,

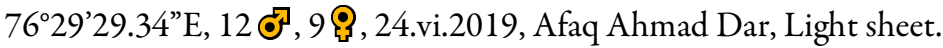

Diagnosis. Expanse: of, 87-88 mm; \&, 104-106 mm. Male: Head and thorax are greenish-grey; abdomen orange. Forewings greenish grey with very numerous faint striated reddish lines; three rufous spots at the end of cell; a dark oblique line from near apex to center of inner margin.

Female: Forewings more prominently striated with rufous; the silvery patches below and beyond cell very large and conjoined, crossed by white streaks above vein 2 and beyond the cell.

Global distribution: India; Srilanka; Myanmar; Australia; Java; Burma

2. Eudocima phalonia (Linnaeus, 1763)

Material Examined: Rajasthan: Alwar, Sariska Tiger Reserve (Kalighati), 27²1’29.95”N, 76²9’29.34” E, 6 F, 10 \&, 27.vi.2019, Afaq Ahmad Dar, Light sheet.

Diagnosis. Expanse: of, 90-103 mm; \&, 94-110 mm. Male: Head and thorax are red-brown suffused with plum color; abdomen orange. Forewings red-brown usually with a greenish tinge and irrorated with dark specks. Hindwings are orange with a large black lunule beyond the lower angle of cell.

Female: Forewings much more variegated and striated with dark red-brown; the reniform dark and sending a spur along median nervure to below the orbicular speck; a triangular white mark usually present on the post medial line below vein 3 . Hind wings are similar to male.

Global distribution: India; Thailand; Australia; Japan; Nepal; New Guinea; Indonesia

3. Dysgonia stuposa (Fabricius, 1794)

Material Examined: Rajasthan: Alwar, Sariska Tiger Reserve (Kalighati), 27²1'29.95”N, 76²9'29.34”E,03, 28.vi.2019, Afaq Ahmad Dar, Light sheet.

Diagnosis. Expanse: $45-49 \mathrm{~mm}$. Head, thorax, and wings are dark-brown. Forewings are with a short basal line; the antemedial line erect and having a broad, white, slightly suffused band beyond it, which varies in width. Hindwings are with a white medial band; the outer margin grey at centre. The typical form stuposa has 
the medial band of the fore wing broad and outwardly diffused; the postmedial line usually with only a slight angle at vein 4 .

Global distribution: India; Philippines; Indonesia; Burma; Africa; Europe; Mauritius

4. Achaea janata (Linnaeus, 1758)

Material Examined: Rajasthan: Alwar, Sariska Tiger Reserve (Kalighati), 27²1'29.95”N, 76029'29.34”E, 05, 28.vi.2019, Afaq Ahmad Dar, Light sheet.

Diagnosis. Expanse: 58-60 mm. Head and thorax pale reddish-brown; mid tibia spined; the tibia fringed with long hair in male; abdomen is fuscous tinged with grey. Forewings are pale reddish brown; the markings usually prominent, but sometimes almost obsolete. Hindwings black, with medial white band; three large white spots on outer margin; the cilia whitish.

Global distribution: India; Pakistan; Mozambique; South Africa

5. Euproctis divisia (Walker, 1855)

Material Examined: Rajasthan: Alwar, Sariska Tiger Reserve (Kalighati), 27²1'29.95”N, 76029'29.34”E, 03, 03.vii.2019, Afaq Ahmad Dar, Light sheet.

Diagnosis. Expanse: 21-26 mm. Head, thorax pure white, and abdomen deep black with orange hair tuft at the tip. Both wings are pure white with shinning black scales at the base of fore wings.

Global distribution: India; Pakistan; Mozambique; South Africa

6. Creatonotos interrupta (Linnaeus, 1767)

Material Examined: Rajasthan: Alwar, Sariska Tiger Reserve (Kalighati), 27²1'29.95”N, 76²9'29.34”E, 05, 07.ix.2019, Afaq Ahmad Dar, Light sheet.

Diagnosis. Expanse: 40-42 mm. Head and thorax pale pinkish ochreous, abdomen crimson above with dorsal and lateral series of black spots. Forewings are pale pinkish ochreous with a broad black fascia below median nervure; two black spots at end of the cell. Hindwings are pale or dark fuscous.

Global distribution: India; Burma; Srilanka; Hong Kong; Pakistan; Thailand; Malaysia; Nepal; China; Bhutan

7. Archerontia styx (Westwood, 1847)

Material Examined: Rajasthan: Alwar, Sariska Tiger Reserve (Karnakabas), 27²5’23.17”N, 76²8'28.87”E, 07, 01.vii.2019, Afaq Ahmad Dar, Light sheet.

Diagnosis. Expanse: 90-120 mm. Head brown; thorax dark blue-grey and abdomen yellow. Forewings are mottled with various shades of brown, fulvous, and grey; three indistinct antemedial lines. Hindwings are yellow with a postmedial black band not reaching the costa or anal angle; a similar submarginal maculate band.

Global distribution: India; Japan; Borneo; Malaysia; Philippines; Sri Lanka; China; Hong Kong

8. Agrius convolvuli (Linnaeus, 1758)

Material Examined: Rajasthan: Alwar, Sariska Tiger Reserve (Karnakabas), 27²5’23.17”N, 76²8'28.87”E, 06, 07.vii.2019, Afaq Ahmad Dar, Light sheet.

Diagnosis. Expanse: 80-120 mm. Head, thorax, and a streak down the vertex of abdomen grey; abdomen with lateral transverse bands of pink and black to each segment. Forewings grey, with black streaks below veins 2 and 3; a highly dentate dark postmedial line met by an irregular black streak from the apex. Hind wings are grey; antemedial, medial, and postmedial piceous bands, the two-former meeting at anal angle, the two latter lunulate.

Global distribution: India; Hong Kong; China; Thailand; Nepal; Java; Africa; Europe; Sri Lanka Borneo

9. Nephele hespera (Fabricius, 1775)

Material Examined: Rajasthan: Alwar, Sariska Tiger Reserve (Karnakabas), 27²5’23.17”N, 76²8'28.87”E, 05, 12.viii.2019, Afaq Ahmad Dar, Light sheet.

Diagnosis. Expanse: 60-70 mm. Head, thorax and abdomen are olive-brown or green; abdomen with lateral black segmental bands. Wings rather short and broad; Forewings are slightly acute; olive-brown or green 
coloured; with six faint waved lines and an angled sub marginal line. Hindwings are red-brown; cilia ochreous. Underside is paler; each wing with 2 transverse lines

Global distribution: India; Australia; Burma; Vietnam; Malaysia; Sumatra; Hong Kong; Thailand; Java; Sri Lanka; Nepal; China

10. Hippotion rosetta (Swinhoe, 1892)

Material Examined: Rajasthan: Alwar, Sariska Tiger Reserve (Karnakabas), 27²5’23.17”N, 76²8'28.87”'E, 04, 13.ix.2019, Afaq Ahmad Dar, Light sheet.

Diagnosis. Expanse: 55-65 mm. Head, thorax, and abdomen pale brown. Forewings pale brown, with a dark speck at end of cell; six oblique lines from near apex to inner margin. Hindwings pink; the black patch at base of hind wing small or completely lacking; outer margin black.

Global distribution: India; China; Thailand; Hong Kong; Vietnam

11. Daphnis nerii (Linnaeus, 1758)

Material Examined: Rajasthan: Alwar, Sariska Tiger Reserve (Karnakabas), 27²5’23.17”N, 76²8'28.87'E, 05, 04.vi.2019, Afaq Ahmad Dar, Light sheet.

Diagnosis. Expanse: 90-110 mm. Head and thorax are green, abdomen paler green. Forewings dark green; a white patch with a black spot on it at base; some medial whitish conjoined bands, rosy towards hind margin; an outwardly oblique band from costa to vein 4 . Hindwings fuscous, with a pale curved submarginal line, beyond which the area is olive.

Global distribution: India; Sri Lanka; Europe; Burma; South Africa; China; Japan; Hong Kong; Thailand Arabia; Nepal; Sumatra

\section{Theretra oldenlandiae (Fabricius, 1775)}

Material Examined: Rajasthan: Alwar, Sariska Tiger Reserve (Karnakabas), 2725'23.17”N, 76²8’28.87”E, 08, 07.vii.2019, Afaq Ahmad Dar, Light sheet.

Diagnosis. Expanse: 60-70 mm. Head, thorax \& abdomen greyish brown. Forewings greyish brown without pink suffusion; the two dorsal lines on abdomen silvery white, as also the oblique stripes on forewing; the sides of abdomen ochreous, not golden. Hindwings with the submarginal band ochreous and narrow

Global distribution: India; Sri Lanka; East Australia; Vanuatu Islands; Australia; New Guinea; Papua

13. Caligula lindia (Moore, 1865)

Material Examined: Rajasthan: Alwar, Sariska Tiger Reserve (Slopka), 27 $14^{\prime} 40.28^{\prime \prime} \mathrm{N}, 7^{\circ} 25^{\prime} 30.29^{\prime \prime} \mathrm{E}$, 02, 01.vi.2019, Afaq Ahmad Dar, Light sheet.

Diagnosis. Expanse: 90-96 mm. Head, thorax, and abdomen are grey; with little dark bands on the abdomen. Forewings have ocellus with no crimson; postmedial lines waved, not highly dentate, no yellow spots. Hindwings have ocellus with crimson only on inner side; two waved post medial lines.

Global distribution: India;Afghanistan; Bhutan; Tibet; China

14. Actias selene (Hubner, 1807)

Material Examined: Rajasthan: Alwar, Sariska Tiger Reserve (Slopka), 27¹4'40.28"N, 76²5'30.29"E, 04, 07.ix.2019, Afaq Ahmad Dar, Light sheet.

Diagnosis. Expanse: 140-182 mm. Head, thorax, and abdomen white. Forewings very pale green, white at base; a dark pink costal fascia, darkest along subcostal nervure; an outwardly-oblique pale yellow antemedial line; dark red-brown lunule at end of a cell, with a grey line on it, bounding around ochreous spot inwardly with the pinkish center. Hindwings are similar to the fore wing; the central portion of the tail pinkish.

Global distribution: India; Nepal; Borneo; Japan; Sri Lanka; China; Taiwan; Pakistan; Afghanistan

15. Spodoptera litura (Walker, 1857)

Material Examined: Rajasthan: Alwar, Sariska Tiger Reserve (Slopka), 27 ${ }^{\circ} 14^{\prime} 40.28^{\prime \prime} \mathrm{N}, 76^{\circ} 25^{\prime} 30.29^{\prime \prime} \mathrm{E}$, 04, 03.x.2019, Afaq Ahmad Dar, Light sheet.

Diagnosis. Expanse: $30-40 \mathrm{~mm}$. Head and thorax pale ochreous suffused with dark brown; abdomen 
paler with tufts slight. Fore wings are pale ochreous much suffused with dark brown; Forewings with some ochreous streaks at base; an angled and oblique subbasal line; a waved and curved antemedial line; the orbicular oblique. Hindwings are opalescent and semi hyaline white, with a dark marginal line.

Global distribution: India; China; Sarawak; Tasmania; Java; Hong Kong; Australia; Sri Lanka

16. Diaphania indica (Saunders, 1851)

Material Examined: Rajasthan: Alwar, Sariska Tiger Reserve (Kalighati), 27²1'29.95”N, 76²9'29.34"E, 04, 07.xi.2019, Afaq Ahmad Dar, Light sheet.

Diagnosis. Expanse: $25-30 \mathrm{~mm}$. Head and thorax black-brown; abdomen white with the 7 th and 8 th segments black; the anal tuft brown and black. Forewings with the costal and inner areas broadly black, leaving a triangular pearly hyaline white patch. Hindwings pearly hyaline white, with a marginal black band broad at costa.

Global distribution: India; Caribbean; USA; China; Indonesia; Taiwan; Mauritius; Fiji.

Table 2. Summary of moths recorded during the survey

\begin{tabular}{|c|c|c|c|c|}
\hline S. No & Family & Sub-family & Species & Author, Year \\
\hline 01 & Erebidae & Calpinae & Eudocima materna* & Linnaeus, 1767 \\
\hline 02 & Erebidae & Calpinae & Eudocima phalonia* & Linnaeus, 1763 \\
\hline 03 & Erebidae & Erebinae & Dysgonia stuposa* & (Fabricius, 1794) \\
\hline 04 & Erebidae & Erebinae & Achaea janata* & Linnaeus, 1758 \\
\hline 05 & Erebidae & Lymantriinae & Euproctis divisia* & Walker, 1855 \\
\hline 06 & Erebidae & Arctiinae & Creatonotos interrupta & (Linnaeus, 1767) \\
\hline 07 & Sphingidae & Sphinginae & Archerontia styx ${ }^{*}$ & Westwood, 1847 \\
\hline 08 & Sphingidae & Sphinginae & Agrius convolvuli* & Linnaeus, 1758 \\
\hline 09 & Sphingidae & Sphinginae & Nephele hespera* & Fabricius, 1775 \\
\hline 10 & Sphingidae & Macroglossinae & Hippotion rosetta ${ }^{*}$ & (Swinhoe, 1892) \\
\hline 11 & Sphingidae & Macroglossinae & Daphnis nerii ${ }^{*}$ & Linnaeus, 1758 \\
\hline 12 & Sphingidae & Macroglossinae & Theretra oldenlandiae * & (Fabricius, 1775) \\
\hline 13 & Saturniidae & Saturniinae & Caligula lindia* & Moore, 1865 \\
\hline 14 & Saturniidae & Saturniinae & Actias selene & Hubner, 1807 \\
\hline 15 & Noctuidae & Noctuinae & Spodoptera litura & Walker, 1857 \\
\hline 16 & Crambidae & Spilomelinae & Diaphania indica & (Saunders, 1851) \\
\hline
\end{tabular}

\section{Discussion}

In the present study of tiger reserve, different habitats were accessed for moth diversity. During the field investigations, mixed riparian forest was highly diverse represented by 8 species, slope forest with moderately diverse represented by 5 species and scrub forest represented by 3 species. The most species rich families were Family Erebidae (05 genera; 06 species) and Sphingidae (06 genera; 06 species), Saturniidae (02 genera; 02 species), Noctuidae (01 genera; 01 species), and Crambidae (01 genera; 01 species). The high species richness of the family Erebidae and Sphingidae can be attributed due to the presence of a large number of grasslands and forests throughout the reserve. Lower species richness of the other families could be improved by comprehensive periodical surveys.

Moths constitute majority of Lepidoptera, and play a pivotal role in maintaining ecological balance of an ecosystem. Due to the anthropogenic activities, there is a loss of biodiversity at an alarming rate. Therefore, our prime priority should be to explore the undiscovered moth fauna, and to report floral and faunal 
components from biodiverse rich pockets at regional and national level, which will ultimately add up to the biodiversity of our Nation. Moths contemplate have been advancing at a moderate pace in our nation because of lack of literature and expertise. The moths, which constitute majority of the Lepidoptera species, don't enjoy the same enthusiasm as butterflies (Scoble, 1992). Most of the moth species are yet to be described, and if described, information present on them in terms of distribution and host plants are poor (Janzen, 1998). Moth Fauna of Rajasthan is very poorly known. Prior to this study, only two studies have been carried out in different parts of Rajasthan for exploring moth diversity. In addition, no study till yet has been carried out in Sariska Tiger Reserve. Sharma (2011) explored the Aravalli Hills of Rajasthan and the lepidopterous insects associated with vegetables and reported 35 species of moths belonging to 11 families from different regions of Aravalli ranges of Rajasthan from September, 2008 to February 2011. Most of the moths belong to the family Crambidae followed by Noctuidae. Sharma (2014) reported 54 species of moths belonging to 10 families from different areas of Aravalli Hill Ranges of Rajasthan, with families Noctuidae and Crambidae dominant in the area. 

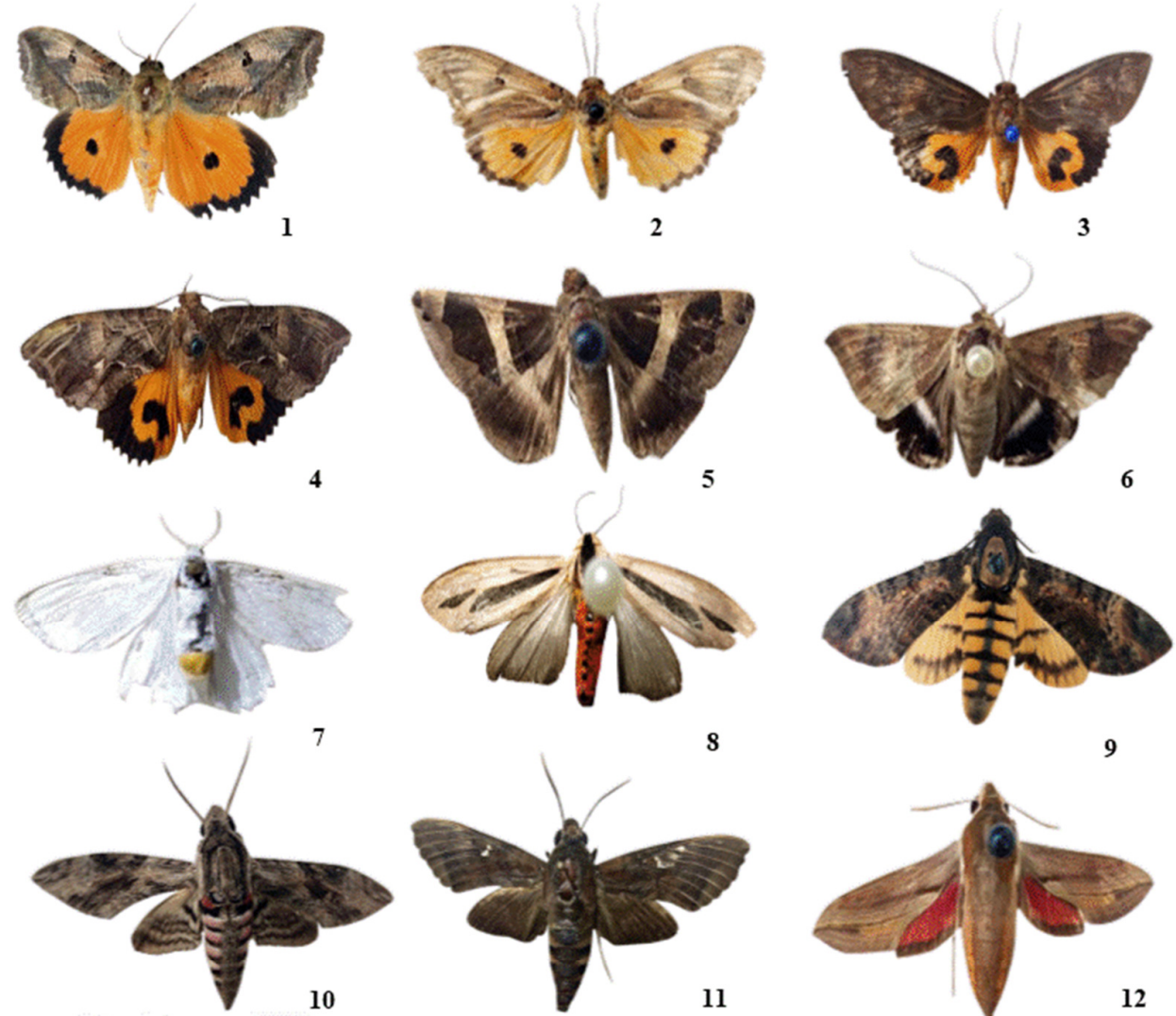

9
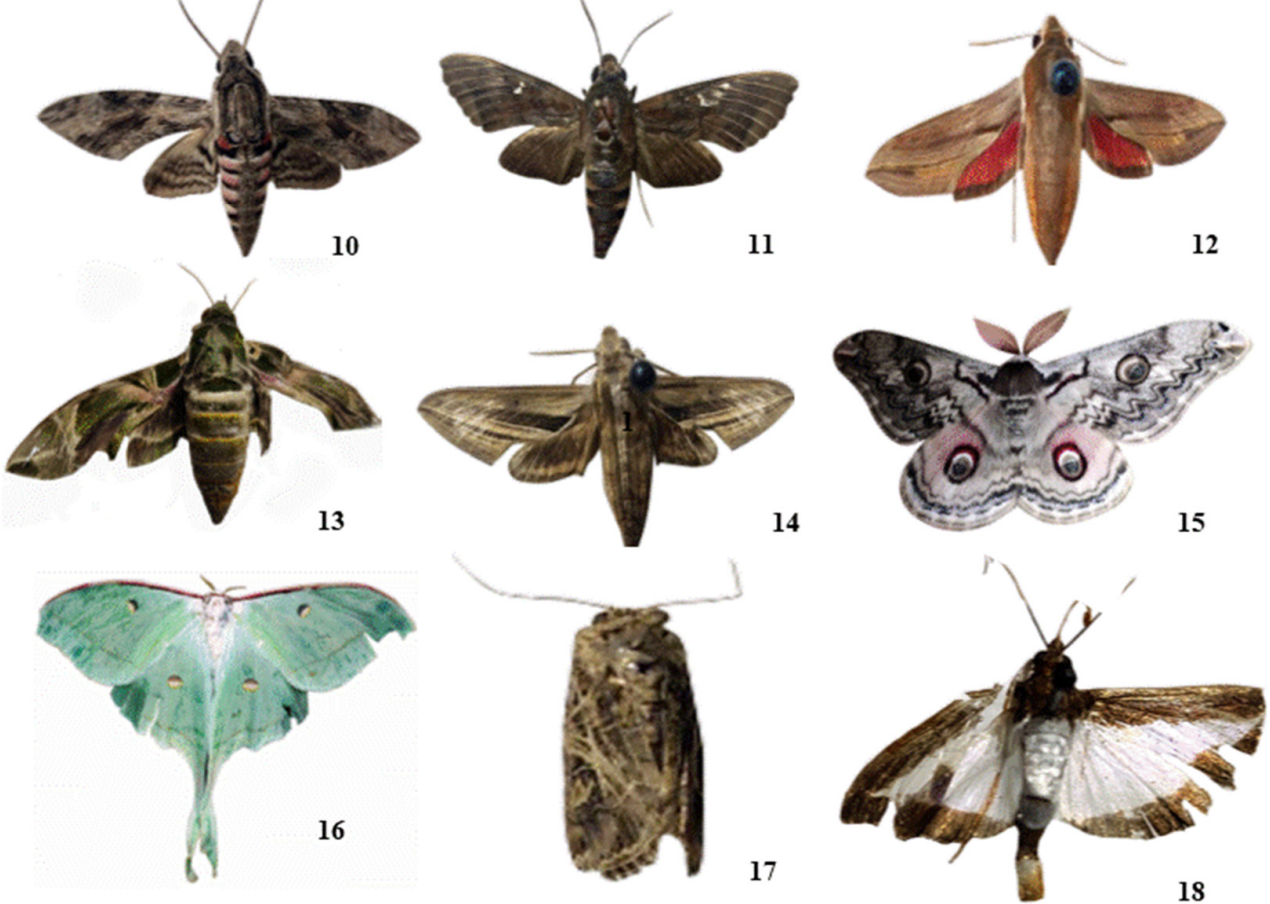

Plate 1. 1-Eudocima materna (Male); 2-Eudocima materna (Female); 3-Eudocima phalonia (Male); 4Eudocima phalonia (Female); 5-Dysgonia stuposa; 6-Achaea janata;7-Euproctis divisia; 8-Creatonotos interrupta; 9-Archerontia styx, 10-Agrius convolvuli; 11- Nephele hespera; 12-Hippotion rosetta; 13Daphnis nerii; 14-Theretra oldenlandiae; 15-Caligula lindia; 16-Actias selene; 17-Spodoptera litura; 18 Diaphania indica 


\section{Conclusions}

The present study reported 16 species of moths belonging to 05 families for the first time in the study area. Yet more investigation and detailed long-term survey is needed to yield significant result of faunal diversity of moth. Sincere efforts towards faunistic survey for moth diversity will enrich the moth fauna of the Rajasthan.

\section{Authors' Contributions}

Both authors read and approved the final manuscript.

\section{Acknowledgements}

Authors are grateful to Chairperson, Department of Zoology, for providing necessary facilities during the course of study and Forest Department Rajasthan for providing permission to work in forest area.

\section{Conflict of Interests}

The authors declare that there are no conflicts of interest related to this article.

\section{References}

Arora GS (1983). On the Lepidopterous fauna of Andaman and Nicobar group of Island (India), Family Arctiidae. Zoological Survey of India 60:1-49.

Barlow HS (1982). An introduction to the moths of South East Asia. The Malayan Nature Society, Kualalumpur pp 1292.

Bell TRD, Scott FB (1937). Fauna of British India, including Ceyon and Burma. Taylor and Francis (Volume 5), London. Bhattacharya DP (1997). Insecta: Pyralidae. In: Director, Zoological Survey of India (Eds), Fauna of West Bengal (Part 7), State fauna series 3, Zoological Survey of India, Kolkata, India pp 319-408.

Champion HG, Seth SK (1968). A revised survey of the forest types of India. New Delhi, India, pp 404.

Chandra K (2007). Moth diversity of Madhya Pradesh and Chhattisgarh, India, and its conservation measures. In: Kendrick RC (Ed). Proceedings of the First South East Asian Lepidoptera Conservation Symposium. Hong Kong 2006. Kadoorie Farm \& Botanic Garden, Hong Kong pp 49-61.

Chandra K, Kumar V, Singh N, Raha A, Sanyal AK (2019). Assemblages of Lepidoptera in Indian Himalaya through long term monitoring plots. Records of the Zoological Survey of India pp 1-457.

Chandra K, Sambath S (2013). Moth diversity of Tawang district, Arunachal Pradesh, India. Journal of Threatened Taxa 5(1):3565-3570. https://doi.org/10.11609/JoTT.o2718.966

Chandra K, Nema DK (2007). Insecta: Lepidoptera: Heterocera (Moths). In: Fauna of Madhya Pradesh (including Chhattisgarh), State Fauna Series, 15(Part-1). Zoological Survey of India pp 347-418.

Dashahre AK, Navanwwthan B, Bhutt P, Mahato S (2014). Medicinal plants of Sariska Tiger Reserve (Rajasthan) India. Journal of Medicinal Plants 2(2):127-136.

Ghosh SK (2003). Fauna of Sikkim. Zooogical Survey of India 9:217-342.

Ghosh SK, Choudhury M (1997). Fauna of West Bengal (Arctiidae). Zoological Survey of India 7:247-274.

Gogoi H, Borah G, Indu H, Habung T (2014). Moths of Arunachal Pradesh: A preliminary report. Bulletin for Life Science 10:16-28.

Gupta SL, Farooqi SI, Chaudhary HS (1984). Taxonomic studies on some of syntype of Indian Lymantriidae in British Museum (Natural History). London Part 5: Lymantria Sp. Riechenbachia Mus Trick Dresden 22:23-29. 
Gurule SA, Nikam SM, Kharat AJ, Gangurde GH (2010). Check-list of owlet and underwing moth (Lepidoptera:Noctuidae) from Nashik district, (MS) India. Flora \& Fauna 16(2):295-304.

Gurule SA, Nikam SM (2011). Inventory of lepidopterous insects in survey for moth diversity. Flora 17(1):165-174.

Gurule SA, Nikam SM (2013a). The moths (Lepidoptera: Heterocera) of northern Maharashtra: a preliminary checklist. Journal of Threatened Taxa 5(12):4693-4713. http://dx.doi.org/10.11609/JoTT.o2555.4693-713

Gurule SA (2013b). Taxonomic study of moths (Lepidoptera: Heterocera) from north Maharashtra, India. Ph.D. thesis submitted to Savitribai Phule Pune University, Pune, pp 250. https://shodhganga.inflibnet.ac.in/handle/10603/98571

Hampson GF (1892). The Fauna of British India, including Ceylon and Burma. Taylor and Francis (Volume 1), London, pp 527.

Hampson GF (1894). The Fauna of British India, including Ceylon and Burma. Taylor and Francis (Volume 2), London, pp 609.

Hampson GF (1895). The Fauna of British India, including Ceylon and Burma. Taylor and Francis (Volume 3), London, pp 546.

Hampson GF (1896). The Fauna of British India, including Ceylon and Burma. Taylor and Francis (Volume 4), London, pp 594.

Holloway JD (1987). The moths of Borneo (Part 3): Lasiocampidae, Eupterotidae, Bombycidae, Brahmaeidae, Saturniidae, Sphingidae. Southdene Sdn. Bhd., Kuala Lumpur, Malaysia.

Holloway JD (1999). The moths of Borneo (part 5): family Lymantriidae. Malayan Nature Journal 53:1-188.

Holloway JD (2005). The moths of Borneo: family Noctuidae, subfamily catocalinae. Malayan Nature Journal 58(1-4):1529. http://dx.doi.org/10.11609/jott.2814.8.5.8756-8776

Janzen DH (1988). Ecological characterization of a Costa Rican dry forest caterpillar fauna. Biotropica 20(02):120-135. https://doi.org/10.2307/2388184

Jonason D, Franzen M, Pettersson LB (2013). Transient peak in moth diversity as a response to organic farming. Basic and Applied Ecology 14(6):515-522. https://doi.org/10.1016/j.baae.2013.07.003

Khan H, Perveen F (2015). Distribution of butterflies' family Nymphalidae in Union Council Koaz Bahram Dheri, Khyber Pakhtunkhwa, Pakistan. Social and Basic Sciences Research Review 31:52-57.

Kirti JS, Singh N (2015). Arctiid moths of India. Nature Books (Volume 1), New Delhi, India.

Kirti JS, Sodhi JS (2001). A systematic list of Pyraustinae of north-eastern India (Pyralidae: Lepidoptera). Zoos' Print Journal 16(10):607-614. https://doi.org/10.11609/JoTT.ZPJ.16.10.607-14

Macgregor CJ, Pocock MJ, Fox R, Evans DM (2015). Pollination by nocturnal Lepidoptera, and the effects of light pollution: a review. Ecological Entomology 40(3):187-198. https://doi.org/10.1111/een.12174

Mandal DK, Ghosh SK (1991). On little-known moths of Tripura, India. Zoological Survey of India 88:299-334

Mandal DK, Ghosh SK (1997). Fauna of West Bengal (Geomtridae). Zoological Survey of India 7:491-532.

Mandal DK, Maulik DR (1997). Fauna of West Bengal (Sphingidae, Lasiocampidae, Lymantridae). Zoological Survey of India 7:613-688

Samways MJ (2007). Implementing ecological networks for conserving insect and other biodiversity. In: Stewart AJA, New TR, Lewis OT (Eds). Insect Conservation Biology. The Royal Entomological Society pp 127-143. https://doi.org/10.1079/9781845932541.0000

Scoble MJ (1992). The Lepidoptera. Form, function and diversity. Oxford University Press, New York, pp 404.

Sevastopulo DG (1956). Notes on Heterocera of Kolkata. Journal of Bombay Natural History Society 54:292-308.

Shahabuddin G, Kumar R (2006). Influence of anthropogenic disturbance on bird communities in a tropical dry forest: role of vegetation structure. Animal Conservation 9(4):404-413. https://doi.org/10.1111/j.14691795.2006.00051.x

Sharma AK, Bisen UK (2013). Taxonomic documentation of insect pest fauna of vegetable ecosystem collected in light trap. International Journal of Environmental Science: Development and Monitoring (IJESDM) 4(3):4-10.

Sharma G (2011). Studies on lepidopterous insects associated with vegetables in Aravali Range, Rajasthan, India. Biological Forum 3(1):21-26

Sharma G (2014). Studies on Odonata and Lepidoptera fauna of foothills of Aravalli Range, Rajasthan. Records of Zoological Survey of India 353:1-104.

Snellen PC, Elwes H J (1890). XVIII. A catalogue of the Pyralidina of Sikkim collected by Henry J. Elwes and the late Otto Möller. Transactions of the Royal Entomological Society of London 38(4):557-647. https://doi.org/10.1111/j.1365-2311.1890.tb03031.x 
Sondhi S, Sondhi Y, Roy P, Kunte K (2020). Moths of India. v. 2.00. Indian Foundation for Butterflies. Retrieved 2021 February 05 from http://www.mothsofindia.org/

Sondhi Y, Sondhi S (2016). A partial checklist of moths (Lepidoptera) of Dehradun, Mussoorie and Devalsari in Garhwal, Uttarakhand, India. Journal of Threatened Taxa 8(5):8756-8776. https://doi.org/10.11609/jott.2814.8.5.87568776

Thomas JA (2005). Monitoring change in the abundance and distribution of insects using butterflies and other indicator groups. Philosophical Transactions of the Royal Society B: Biological Sciences 360(1454):339-357. https://doi.org/10.1098/rstb.2004.1585

Uniyal VP, Dey P, Sanyal AK (2016). Diversity of moths Lepidoptera: Heterocera) and their potential role as a conservation tool in different protected areas of Uttarakhand. Wildlife Institute of India, Dehradun (DST Project Completion Report) pp 105.

van Nieukerken EJ, Kaila L, Kitching IJ, Kristensen NP, Lees DC, Minet J, ... Zwick A (2011). Order Lepidoptera. In: Zhang Z-Q (Ed). Animal Biodiversity: An Outline of Higher-Level Classification and Survey of Taxonomic Richness. Zootaxa 3148:212-221. https://doi.org/10.11646/zootaxa.3148.1.41

Wickramasinghe LP, Harris S, Jones G, Vaughan Jennings N (2004). Abundance and species richness of nocturnal insects on organic and conventional farms: effects of agricultural intensification on bat foraging. Conservation Biology 18(5):1283-1292. https://doi.org/10.1111/j.1523-1739.2004.00152.X

OPEN ACCESS

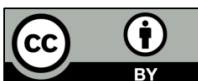

The journal offers free, immediate, and unrestricted access to peer-reviewed research and scholarly work. Users are allowed to read, download, copy, distribute, print, search, or link to the full texts of the articles, or use them for any other lawful purpose, without asking prior permission from the publisher or the author.

License - Articles published in Notulae Scientia Biologicae are Open-Access, distributed under the terms and conditions of the Creative Commons Attribution (CC BY 4.0) License.

(c) Articles by the authors; SHST, Cluj-Napoca, Romania. The journal allows the author(s) to hold the copyright/to retain publishing rights without restriction. 